\title{
Postpartum glucose tolerance test application rates and non-application causes in gestational diabetes mellitus cases
}

\author{
Engin Korkmazer', Emine Arslan², Özgür Akkurt ${ }^{3}$, Muzaffer Temur ${ }^{1}$, Tayfur Çift' ${ }^{1}$, Emin Üstünyurt' \\ ${ }^{\prime}$ Clinics of Obstetrics \& Gynecology, Bursa Yiiksek İhtisas Training and Research Hospital, Bursa, Turkey \\ ${ }^{2}$ Department of Obstetrics \& Gynecology, Faculty of Medicine, Hitit University, Corum, Turkey \\ ${ }^{3}$ Clinics of Perinatology, Bursa Yiiksek İbtisas Training and Research Hospital, Bursa, Turkey
}

\begin{abstract}
Objective: Gestational diabetes mellitus is a health problem with long-term consequences that concern the general population seen at increasing rates. This population should be followed up more closely and the reasons of those who do not apply should be investigated and these people should be included in follow-up protocols. In this study, we investigated the rates of application for postpartum glucose tolerance tests of women who had gestational diabetes mellitus diagnosis in a low socioeconomic population. We also examined the reasons for not applying to have a glucose tolerance test.

Methods: A total of 738 gestational diabetes patients with low socioeconomic status who were followed-up and treated at a tertiary care center were included in the study. These patients were reached after the 8th postpartum period to investigate the cases of having glucose tolerance testing and the reasons for not having it.

Results: 227 (30.7\%) of the 738 patients who participated in the study, had applied for glucose tolerance testing in the postpartum period. Of the remaining 511 patients, 337 (65.9\%) indicated that they did not apply because they were not informed about it, 98 $(19.1 \%)$ of them indicated the financial impossibilities as the reason of not applying, 40 (7.8\%) of them did not apply because their husbands did not take them the health center, $36(7.2 \%)$ indicated that they did not attend because they did not consider it necessary.

Conclusion: In the postpartum period, glucose test admission rates are quite low in the low socioeconomic population. It is clear that there is a need for new health policies and follow-up systems following this population in terms of long-term outcomes.
\end{abstract}

Keywords: Gestational diabetes, glucose tolerance testing, postpartum, type 2 diabetes.
Özet: Gestasyonel diabetes mellitus olgularında postpartum glukoz tolerans testi uygulamasının oranları ve uygulanmamasının nedenleri

Amaç: Gestasyonel diabetes mellitus, artan oranlarda görülen ve genel popülasyonu ilgilendiren uzun vadeli sonuçlara sahip bir sağlık sorunudur. Bu popülasyon daha yakından takip edilmeli, uygulanmama nedenleri araştırılmalı ve bu kişiler takip protokollerine dahil edilmelidir. Bu çalışmada, düşük sosyo-ekonomik popülasyonda bulunan ve gestasyonel diabetes mellitus tanısı almış kadinlarda postpartum glukoz tolerans testlerinin uygulanma oranlarını araştırdık. Ayrıca, glukoz tolerans testi için başvurmama nedenlerini de inceledik.

Yöntem: Çalışmaya, düşük sosyo-ekonomik düzeyde olan, üçüncü basamak bakım merkezinde takip ve tedavi edilen toplam 738 gestasyonel diyabet hastası dahil edildi. Glukoz tolerans testi yap1lan olguları ve bu testi yaptırmama nedenlerini araştırmak amacıyla bu hastalara 8. postpartum dönemden sonra ulaşıldı.

Bulgular: Çalışmaya katılan 738 hastanın 227'si (\%30.7) postpartum dönemde glukoz tolerans testine başvurmuştu. Kalan 511 hastanın 337'si (\%65.9) bilgilendirilmedikleri için başvurmadığını, 98'i (\% 19.1) başvurmama nedeni olarak mali güçlükler yaşadığını, 40 '1 (\% 7.8) eşlerinin kendilerini sağlık merkezine getirmediği için başvurmadığını, 36'sı (\% 7.2) ise testin gerekli olmadığını düşündükleri için gelmediklerini belirtti.

Sonuç: Postpartum dönemde glukoz tolerans testi başvuru oranları, düşük sosyo-ekonomik popülasyonda oldukça düşüktür. Uzun vadeli sonuçlar bakımından yeni sağlık politikalarına ve bu popülasyonu takip etmek için takip sistemlerine gereksinim olduğu açıktır.

Anahtar sözcükler: Gestasyonel diyabet, glukoz tolerans testi, postpartum, tip 2 diyabet.
Correspondence: Engin Korkmazer, MD. Clinic of Obst. \& Gyn., Bursa Yüksek İhtisas Training and Research Hospital, Bursa, Turkey. e-mail: ekorkmazer@yahoo.com Received: March 20, 2018; Accepted: May 13, 2018

Please cite this article as: Korkmazer E, Arslan E, Akkurt Ö, Temur M, Çift T, Üstünyurt E. Postpartum glucose tolerance test application rates and non-application causes in gestational diabetes mellitus cases. Perinatal Journal 2018;26(2):69-73.

(c)2018 Perinatal Medicine Foundation
Available online at: www.perinataljournal.com/20180262003 doi: $10.2399 /$ prn.18.0262003 QR (Quick Response) Code:

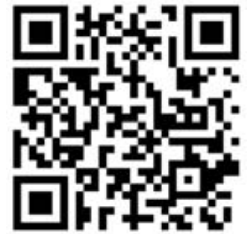




\section{Introduction}

Gestational diabetes mellitus (GDM) first recognized during pregnancy from those whose disease is a transient manifestation of pregnancy-related insulin resistance. ${ }^{[1]}$ GDM is a health problem seen at increasing rates. ${ }^{[2]}$ Although GDM usually recovers after pregnancy, it carries the risk for dyslipidemia, obesity, hypertension, cardiovascular diseases and other metabolic disorders, especially type 2 diabetes in long term. ${ }^{[3,4]}$ Because of longterm risks, postpartum glucose screening is recommended by all health systems. NICE state that up to $50 \%$ of women diagnosed with gestational diabetes develop type 2 diabetes within 5 years of the birth. ${ }^{[5]}$

Women who are diagnosed as GDM are more motivated for treatment during pregnancy but do not show enough interest in the glucose test after pregnancy. ${ }^{[6,7]}$ Patients referred to the glucose tolerance testing (GTT) have a higher admission rate, especially in the high socioeconomic category, but remain lower in low socioeconomic group. ${ }^{[8]}$ Therefore, the objective of this study was to conduct an in-depth exploration of the experiences of, and perspectives on postpartum GTT screening with low socioeconomic status women diagnosed with GDM.

\section{Methods}

This is a cross-sectional study conducted between January 2015 and June 2016 at the Bursa Yüksek İhtisas Training and Research Hospital, which is a tertiary care center. In this period, 738 of 926 patients with low socioeconomic status and no previous diagnosis of diabetes or with no history of GDM in previous pregnancies that were reached by the hospital records and telephone numbers diagnosed with GDM were included in the study. Low socioeconomic status defined according to Turkish Statistical Institute January 2015 data. The study was approved by the local ethics committee (Ethics Committee of Bursa Yüksek İhtisas Training and research Hospital, 613-2014).

A one-step approach was used in the diagnosis of patients. In 2010, International Association of Diabetes and Pregnancy Study Group (IADPSG) bring new criteria for the diagnosis of GDM. New IADPSG criteria were mainly prepared by focusing on the perinatal risk of parameters which are $>90$ percentile. For the diagnosis, the criteria endorsed by the American Diabetes
Association (ADA) were used (one-step 75-g OGTT) ${ }^{[9]}$ According to ADA patient diagnosed GDM if one of three values (Fasting $\geq 92 \mathrm{mg} / \mathrm{dL}$, first hour $\geq 180 \mathrm{mg} / \mathrm{dL}$, second hour $\geq 153 \mathrm{mg} / \mathrm{dL}$ ) are elevated. Patients receiving GDM diagnosis were followed up in the same diabetes clinic and informed by the diabetes nurse. Patients were informed about GDM when they were discharged from the hospital after the follow-up period of birth and they were called for the diabetes screening at postpartum 6th week.

All of the patients were called by telephone after the postpartum 12 th week and a verbal questionnaire was applied after their verbal permission was obtained. Survey responses were recorded in the computer afterwards. At the end of the survey, the responses were confirmed by reading the participants again. All patients were asked the same questionnaire by the same researcher. During the telephone survey of all the participants were asked the total monthly income of the family and the participants whose income was below the poverty line were included in the study. Postpartum diabetes screening was defined as women who received an oral GTT at 6 to 12 weeks postpartum.

Basic demographic data and survey results were recorded in the SPSS v21 software (SPSS Inc., Chicago, IL, USA).

\section{Results}

The mean age of women with GDM was 30.8 \pm 5.1. The demographic characteristics of the patients are given in Table 1. 427 (57.8\%) of the participants were high school graduates, $249(33.7 \%)$ were primary school graduates and $62(8.5 \%)$ were illiterate while none of them were university graduates.

Of the 738 patients who participated in the study, $227(30.7 \%)$ reapplied for GTT in the postpartum peri-

Table 1. Demographic characteristic of study population $(n=738)$.

\begin{tabular}{lc} 
& Mean \\
Age & $30.8 \pm 5.1$ \\
Gravida & $1.8 \pm 1.1$ \\
Gestational week at birth & $38.9 \pm 1.7$ \\
Pre-eclampsia & $71(9.6 \%)$ \\
Cesarean & $84(11.3 \%)$ \\
\hline
\end{tabular}


od, while the remaining 511 (69.3\%) did not reapply for GTT. As a result of the survey, the reasons for not having GTT were collected under 4 main headings. Of 511 patients stated that they did not go to the hospital because they were not informed enough and did not know about long-term risks, 98 (19.1\%) said they did not go because of financial difficulties and health insurance problems, $40(7.8 \%)$ of the participants stated that they could not apply because their husbands did not take them to hospital, and $36(7.2 \%)$ of them claimed that they did not consider it necessary (Fig. 1).

\section{Discussion}

In our study, it is seen that the majority of patients with low socioeconomic status $(69.3 \%)$ did not return to the health facility for GTT in the postpartum period. This creates a public health problem in terms of long-term complications. Women with GDM history are seven times more likely to develop type 2 diabetes during their lifetime compared with women without GDM history. ${ }^{[10]}$ At the same time, it poses a risk for early diabetes in subsequent pregnancies. In the study by Ekelund et al. it was shown that $51 \%$ patients with GDM had impaired glucose tolerance and 30\% developed diabetes mellitus over 5 years. ${ }^{[1]}$ Gestational requirement for insulin and early gestational age at the time of diagnosis (ie, less than 24 weeks of gestation) are the major risk factors for the development of type 2 diabetes mellitus. In women who used insulin during pregnancy, relative measures of association range between 2.8 and $4.7 .^{[12]}$

Studies have shown that the risk for type 2 diabetes is significantly reduced if high-risk individuals are identified early and lifestyle changes are made. Tuomilehto et al. showed that, lifestyle changes may reduce to type 2 diabetes rate up to $58 \% .^{[13]}$ These patients need to be recognized early and referred to lifestyle changes and treatment if necessary. ${ }^{[14]}$ It is not easy to make lifestyle changes in the populations with low socioeconomic status. When evaluated in terms of dietary changes, as the socioeconomic level decreases, the predominant eating habits of carbohydrates increase and the protein weighted diet decreases.

Postpartum GTT admission rates are high in developed countries. This ratio was found to be $85 \%$ in the study of Paez et al. Halle et al. found this rate as

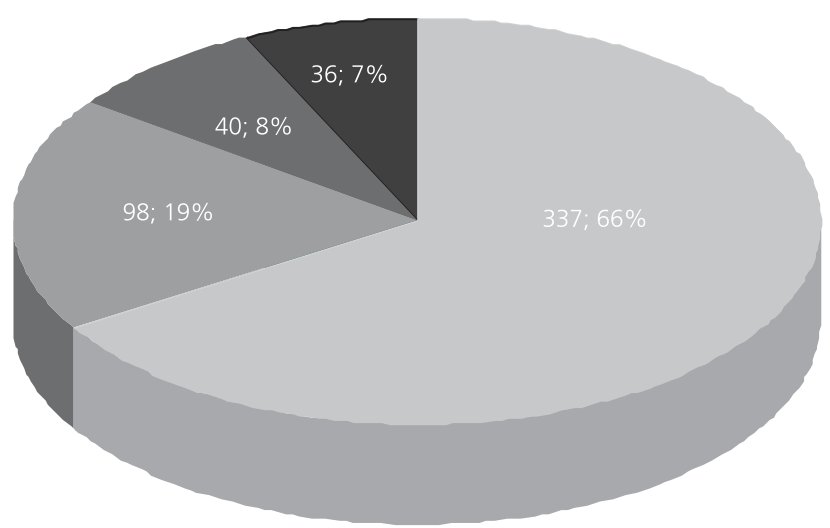

$$
\begin{aligned}
& \text { They were not informed about test } \\
& \text { Financial issues } \\
& \text { Their husbands did not take them the health center } \\
& \text { They did not consider it necessary }
\end{aligned}
$$

Fig. 1. Reasons for not attending to postpartum GTT ( $n=511)$

97\%. In our low socioeconomic status population, it was found to be $30.7 \% .^{[15,16]}$

The majority of patients ( $\mathrm{n}=337,65.9 \%)$ who did not apply for postpartum GTT said they were not adequately informed and they were not aware of the longterm complications. Women in this group indicated that they would make a postpartum GTT if they were aware of long-term risks. Disagreements among some health professionals regarding postpartum GTT make it difficult for patients to be referred to health care facilities. ${ }^{[17]}$ Having different views of major health organizations, especially ADA, The American College of Obstetricians Gynecologists (ACOG) and World Health Organization (WHO), leads to confusion in this way. In addition, there are no precise criteria about who will (obstetrics, endocrinologists, family physicians) perform postpartum GTT screening in most countries. Turkish Ministry of Health recommend GTT screening between 24th and 28th gestational weeks in low risk population at pregnancy management guideline. ${ }^{[18]}$ Turkish Perinatology Society recommends single-step 75-g diagnostic test for Turkish population. They stated that this approach seems more appropriate in terms of costs and patient compliance. ${ }^{[19]}$

$98(19.1 \%)$ of the patients who did not participate in the postpartum GTT screening indicated that they did not have sufficient financial means to reach and 
obtain this test. Some of the people at low socioeconomic status are not covered by health insurance, so they have difficulties at paying for these tests. At the same time this group also has difficulty about accessing the health facility. Normalization of blood glucose values in the early postpartum period leads the people not to have postpartum GTT. Especially women who do not see familial support excuse the absence of time and do not apply for postpartum GTT screening. ${ }^{[8]}$ The likelihood of long-term dieting and life-limiting measures also reduces the rate of patients applying to the postpartum GTT $^{[20]}$ In our population, 36 (7.2\%) women did not apply because they did not consider postpartum GTT necessary.

Clark et al. showed that the rate of having postpartum GTT was higher in the population that was monitored and stimulated by the health system. ${ }^{[21]}$ Problems related to health insurance in the low socioeconomic populations as in our study also affect the rate of postpartum GTT admission. 98 (19.1\%) of the patients in our population, showed health insurance problems as the cause for not applying. It is known that education level also affects the rates of postpartum GTT applications. ${ }^{[2]}$ In our population, $62(8.5 \%)$ participants were illiterate while none of the participants were university graduates.

Forty $(7.8 \%)$ of our patient population stated that they could not make the postpartum GTT because their partners did not take them to the health institution for screening tests. It seems that family members should also be educated about GDM. Bandyopadhyay et al. showed that the rate of postpartum GTT admission increased if family members participated in diabetes education. ${ }^{[8]}$

One of the main limitations of this study is the lack of long-term follow-up results. It is not known if diabetes developed or not in the long-term follow-up of the population at risk. Also the results of subsequent pregnancies are not known for our study group.

All populations have different excuses not to apply for postpartum GTT. The most common cause in a study conducted in Canada was the lack of adequate time, while the most common cause in a study in the USA was long-term treatment needs. ${ }^{[19,23]}$ In our population, the most common cause is not to be informed sufficiently.
For the clinical practice, this study suggests that patients and their relatives should be adequately informed in the postpartum period before being discharged from the hospital. At the same time, this population should not be lost during the postpartum period due to health insurance problems. It is thought that sending mails or making reminder talks by telephone to the participants may increase the admission rate for postpartum GTT.

\section{Conclusion}

In our study it was found that patients with low socioeconomic status had a very low rate of admission to the GTT in the postpartum period. The follow-up of this group of patients and postpartum GTT applications should be considered as a public health problem and family physicians and obstetricians work in harmony to protect these patients from long-term complications.

Conflicts of Interest: No conflicts declared.

\section{References}

1. American Diabetes Association. 2. Classification and diagnosis of diabetes: standards of medical care in diabetes-2018. Diabetes Care 2018;41(Suppl 1):S13-27.

2. Lipscombe LL, Hux JE. Trends in diabetes prevalence, incidence, and mortality in Ontario, Canada 1995-2005: a population-based study. Lancet 2007;369:750-6.

3. Kaul P, Savu A, Nerenberg KA, Donovan LE, Chik CL, Ryan $\mathrm{EA}$, et al. Impact of gestational diabetes mellitus and high maternal weight on the development of diabetes, hypertension and cardiovascular disease: a population-level analysis. Diabet Med 2015;32:164-73.

4. Feig DS, Zinman B, Wang X, Hux JE. Risk of development of diabetes mellitus after diagnosis of gestational diabetes. CMAJ 2008;179:229-34.

5. National Collaborating Centre for Women's and Children's Health (UK). Diabetes in pregnancy: management of diabetes and its complications from preconception to the postnatal period. NICE Guideline, No. 3. London: National Institute for Health and Care Excellence (UK); 2015.

6. Ferrara A, Peng T, Kim C. Trends in postpartum diabetes screening and subsequent diabetes and impaired fasting glucose among women with histories of gestational diabetes mellitus: a report from the Translating Research Into Action for Diabetes (TRIAD) Study. Diabetes Care 2009;32:269-74.

7. Kwong S, Mitchell RS, Senior PA, Chik CL. Postpartum diabetes screening: adherence rate and the performance of fasting plasma glucose versus oral glucose tolerance test. Diabetes Care 2009;32:2242-4. 
8. Bandyopadhyay M, Small R, Davey MA. Attendance for postpartum glucose tolerance testing following gestational diabetes among South Asian women in Australia: a qualitative study. J Womens Health Issues Care 2015;4:1.

9. American Diabetes Association. Standards of medical care in diabetes 2016: Summary of revisions. Diabetes Care 2016;39 Suppl 1:S4-5.

10. Bellamy L, Casas JP, Hingorani AD, Williams D. Type 2 diabetes mellitus after gestational diabetes: a systematic review and meta-analysis. Lancet 2009;373: 1773-9.

11. Ekelund M, Shaat N, Almgren P, Groop L, Berntorp K. Prediction of postpartum diabetes in women with gestational diabetes mellitus. Diabetologia 2010;53:452-7.

12. Baptiste-Roberts K, Barone BB, Gary TL, Golden SH, Wilson LM, Bass EB, et al. Risk factors for type 2 diabetes among women with gestational diabetes: a systematic review. Am J Med 2009;122:207-14.

13. Tuomilehto J, Lindstrom J, Eriksson JG, Valle TT, Hamalainen H, Ilanne-Parikka P, et al.; Finnish Diabetes Prevention Study Group. Prevention of type 2 diabetes mellitus by changes in life style among subjects with impaired glucose tolerance. N Engl J Med 2001;344:1343-50.

14. Evans MK, Patrick LJ, Wellington CM. Health behaviours of postpartum women with a history of gestational diabetes. Can J Diabetes 2010;34:227-32.

15. Paez KA, Eggleston EM, Griffey SJ, Farrar B, Smith J, Thompson J, et al. Understanding why some women with a history of gestational diabetes do not get tested for diabetes. Womens Health Issues 2014;24:e373-9.

16. Hale NL, Probst JC, Liu J, Martin AB, Bennett KJ, Glover S. Postpartum screening for diabetes among Medicaid-eligible
South Carolina women with gestational diabetes. Womens Health Issues 2012;22:e163-9.

17. Bentley-Lewis R, Levkoff S, Stuebe A, Seely EW. Gestational diabetes mellitus: postpartum opportunities for the diagnosis and prevention of type 2 diabetes mellitus. Nat Clin Pract Endocrinol Metab 2008;4:552-8.

18. Riskli Gebelikler Yönetim Rehberi. T.C. Sağlık Bakanlığg Türkiye Halk Sağglığ Kurumu Kadın ve Üreme Sağlığı Daire Başkanlığı, Yayın No: 926. Ankara: T.C. Sağlık Bakanlığı; 2014.

19. Şen C, Yayla M, Api O, Yapar Eyi EG, Artunç Ülkümen B. Diabetes in pregnancy: diagnosis and treatment. Practice Guidelines of Turkish Perinatology Society. Perinatal Journal 2016;24:110-27.

20. Bennett WL, Ennen CS, Carrese JA, Hill-Briggs F, Levine DM, Nicholson WK, et al. Barriers to and facilitators of postpartum follow-up care in women with recent gestational diabetes mellitus: a qualitative study. J Womens Health (Larchmt) 2011;20:239-45.

21. Clark HD, Graham ID, Karovitch A, Keely EJ. Do postal reminders increase postpartum screening of diabetes mellitus in women with gestational diabetes mellitus? A randomized controlled trial. Am J Obstet Gynecol 2009;200:634.e1-7.

22. Tovar A, Chasan-Taber L, Eggleston E, Oken E. Postpartum screening for diabetes among women with a history of gestational diabetes mellitus. Prev Chronic Dis 2011;8:A124.

23. Keely E, Clark H, Karovitch A, Graham I. Screening for type 2 diabetes after gestational diabetes. Can Fam Physician 2010; 56:558-63. 